\title{
Manic episode associated with Varenicline treatment in a patient with a history of depression
}

\author{
Depresyon öyküsü olan bir hastada Vareniklin tedavisi ile ilişkili manik nöbet \\ Pınar Kızılay Çankaya1', Evrim Özkorumak Karagüzel2, Ahmet Tiryaki³ \\ ${ }_{1}^{1}$ M. D., Ankara Training and Research Hospital, Psychiatry Clinic, Ankara, Turkey https://orcid.org/0000-0001-9663-6000 \\ 2Prof. Karadeniz Technical University School of Medicine, Department of Psychiatry, Trabzon. Turkey https://orcid.org/0000-0002-0734-5437 \\ 3Prof., İstanbul Aydın University School of Medicine, Department of Psychiatry, İstanbul https://orcid.org/0000-0001-8923-6869
}

\begin{abstract}
SUMMARY
Varenicline is an alpha 4 beta 2 nicotinic receptor partial agonist with dopaminergic effects. It is an effective and widely used agent approved for smoking cessation. Depressive mood, sleep disorder, suicide, agitation, aggression, psychotic and manic symptoms have been reported during the use of varenicline. We report the case of a 48-year-old woman with a history of major depression who was admitted to the hospital with the diagnosis of mania with psychotic features at the end of the 12-week varenicline treatment. She was admitted to the psychiatry clinic for mystic grandiose and reference delusions, auditory and visual hallucinations, irritability, insomnia, and rapid speech. She was in antidepressant treatment with $100 \mathrm{mg} /$ day sertraline for 2 years and was euthymic for the last 18 months. In her history, she never had symptoms of mania or hypomania or any psychiatric admission before. In the first mental status examination, the Young Mania Rating Scale (YMRS) score was 33. On the twenty-eighth day of the hospitalization, the patient was discharged with the treatment of olanzapine $20 \mathrm{mg} /$ day and clonazepam $0.5 \mathrm{mg} /$ day since her YMRS score improved to 14 . In spite of the fact that the core components of varenicline associated mania stay subtle, the present case report features the significance of monitoring for potential adverse reactions with the use of varenicline in patients with a history of depression, particularly when utilized in combination with antidepressants.
\end{abstract}

Key Words: Mania, psychotic features, smoking cessation, varenicline

(Turkish J Clinical Psychiatry 2020;23:239-243)

DOI: $10.5505 / \mathrm{kpd} .2020 .61214$

\section{ÖZET}

Vareniklin dopaminerjik etkileri de olan bir alfa 4 beta 2 nikotinik reseptör parsiyel agonistidir. Sigara bırakma tedavisinde onaylanmış etkili ve yaygın şekilde kullanılan bir ajandır. Vareniklin kullanımı sırasında depresif duygudurum, uyku bozukluğu, intihar, ajitasyon, saldırganlık ve psikotik ve manik belirtiler bildirilmiştir. Bu olgu sunumunda 12 haftalık vareniklin tedavisinin ardından psikotik özellikli mani tanısıyla hastaneye yatırılan ve depresyon öyküsü olan 48 yaşında bir kadın hastayı sunuyoruz. Hasta dini grandiyöz ve referans sanrıları, işitsel ve görsel halüsinasyonlar, irritabilite, uykusuzluk ve hızlı konuşma belirtileriyle psikiyatri kliniğine kabul edildi. 2 yıldır sertralin 100 mg/gün tedavisi altında ve son 18 aydır ötimikti. Daha önce hiç mani/hipomani belirtisi ya da psikiyatrik yatış öyküsü yoktu. ilk ruhsal durum muayenesinde Young Mani Derecelendirme Ölçeği (YMDÖ) 33 puan olarak değerlendirilen hasta, yatışının 28. gününde olanzapin $20 \mathrm{mg} / \mathrm{gün}$ klonezapam $0.5 \mathrm{mg} / \mathrm{gün}$ tedavisiyle taburcu edildiğinde YMDÖ puanı 14 olarak değerlendirildi. Vareniklin ile ilişkili maninin merkezi mekanizmaları halen tam anlaşılmamış olsa da, olgumuz depresyon öyküsü olan hastalarda özellikle antidepresanlarla birlikte kullanıldığında vareniklinin potansiyel yan etkilerinin dikkatle izlenmesinin önemini vurgulamaktadır.

Anahtar Sözcükler: Mani, psikotik özellikler, sigara bırakma, vareniklin 


\section{INTRODUCTION}

Nicotine dependence is one of the most important public health problems because of the morbidity and mortality associated with smoking. Also, it is known that nicotine dependence rates are extremely high in patients with mental illness (1). Varenicline is an $a 4 \beta 2$ nicotinic acetylcholine receptor partial agonist, approved by Food and Drug Administration (FDA) in 2006 for smoking cessation. Although it is not as potent as nicotine, it allows the release of dopamine from the nucleus accumbens so that dopamine is released in a continuous medium dose (2). By its antagonist effects, even if you take nicotine while using varenicline, there will not be an increase in dopamine release. It has shown efficacy over placebo and bupropion in manufacturer-sponsored trials (2).

There have been many case reports about psychiatric adverse effects associated with varenicline since its approval for the market (FDA alert, 2008). Following these findings, the FDA feel the necessity for a new black box warning, headlining the risk of developing psychiatric symptoms for Varenicline in July 2009 (3).

In spite of the existence of post-marketing concerns for neuropsychiatric adverse events, no significant increase in these events with varenicline compared to placebo was observed following randomized controlled trials, systematic reviews and meta-analyses of pharmacological interventions for smoking cessation $(4,5,6,7,8,9,10,11,12)$

There have been also several studies involving people with mental illness; however, no meaningfully increased risk of neuropsychiatric adverse events and/or exacerbation of mental illness during treatment with varenicline was found in these studies $(13,14,15,16,17)$. Yet, those studies are open to criticism because of being open-label, uncontrolled, and/or underpowered, rendering them inadequate to determine the risk of neuropsychiatric adverse events (18)

Published case reports point to the possibility of causal association between varenicline and neuropsychiatric adverse events (18). Besides, people with pre-existing psychiatric illness appear to have a greater risk of developing such adverse events (18).
Varenicline has been reported to induce hypomanic/manic episodes in patients with a pre-existing bipolar disorder $(19,20,21)$ and mixed mood and psychotic episodes or mania in patients with a history of depression in recent studies $(22,23,24)$. Besides, the reports of mania in patients who had no previous history of psychiatric disease during varenicline use have also been made $(25,26,27,28)$.

Many problems arise in ascribing mania with the effects of medication. A great number of reports involve individual cases (29). Mania may occur by chance association during drug treatment, especially in patients prone to mood disorder (29). Thus, it is very likely that some patients will become manic during coincidental drug treatment (29). If the manic symptoms abate following the discontinuation of the drug and recur on rechallenge, establishing drug treatment as a causative agent in the individual patient is plausible; however, there is hardly any such information (29). Anti-parkinsonian drugs, corticosteroids, anabolic-androgenic steroids, antidepressants, antipsychotics, and many other drugs have been reported to be associated with manic symptoms.

Therefore, manias secondary to drugs are widely considered to be adverse drug events rather than indicators of a bipolarity; secondary manias typically resolve after drug cessation with time-limited symptomatic management as needed $(30,31)$. The reflection of this perspective is noticed in DSM-IV, which classifies antidepressant-induced manias not as a subtype of bipolar illness, but as a substanceinduced mood disorder (32). Conversely, DSM-5 indicates that hypomanic/manic episodes that occur during antidepressant treatment are, in certain circumstances, acknowledged as criteria for bipolar disorder (33). As a result, depressed patients developing mania or hypomania during antidepressant treatment, who are diagnosed with "substance-induced disorder" according to DSM IV-TR criteria, can be diagnosed as bipolar I or II according to DSM-5 criteria $(33,34)$.

In this case report, we present a 48-year-old female patient with a history of depression and a newonset manic episode after the discontinuation of varenicline treatment.

\section{CASE}

A 48-year-old married woman with a history of major depression was admitted to the psychiatry 
clinic for mystic grandiose and reference delusions, auditory and visual hallucinations, irritability, insomnia, and rapid speech. She was in antidepressant treatment with $100 \mathrm{mg} /$ day sertraline for 2 years and was euthymic for the last 18 months. In her history, she never had symptoms of mania or hypomania or any psychiatric admission before. In family history, her mother had a history of recurrent depressive episodes with seasonal patterns. In addition, the mother was on antidepressant treatment and euthymic currently and never had symptoms of mania or hypomania.

The patient does not have any significant physical health problems or any ongoing major psychosocial stressors. She does not have a history of alcohol or drug use. She has been a smoker of 20 cigarettes per day since the age of 25 years. In January 2010, she wanted to stop smoking and was prescribed varenicline by her doctor. The dose was titrated to 1 -mg BID by day 8 and continued up to 12 weeks. On day 14, she stopped smoking with no withdrawal symptoms. She had no mood or behaviour changes during the 12-week treatment period. At the end of 12 weeks, she stopped varenicline and 2 days after discontinuation the patient developed restlessness, insomnia, irritability and acted strangely to her husband. The treatment protocol was presented in Figure 1.

Her husband also reported that she was more talkative than usual and became irritable and easily got nervous. She displayed reference ideas like believing that the things she saw in daily life had "special meaning" to her. She stopped her sertra- line treatment because she thought that she had already recovered so she didn't need drugs anymore and she was believing that she was a "healer". She was thinking that she was given some special missions by God, one of which was to smoke cigarettes from now on, which may also be interpreted as the patient's nicotine craving. Since then she had started to smoke 40 cigarettes/day, which was two times more than before commencing varenicline therapy.

She was taken to the emergency clinic by her husband since her symptoms worsened. On the first mental status examination in the emergency unit, her affect was labile and her mood was elevated and irritable. She had mystic grandiose delusions and auditory and visual hallucinations. She showed the pressure of speech. Her insight was impaired and her judgment was poor. She was admitted to the psychiatry clinic with a diagnosis of mania with psychotic features. On admission, she was delusional and agitated. Her vital signs were stable and her physical examination including neurological examination was normal. No abnormalities were observed in complete blood count, renal function tests, liver function tests, blood glucose, serum electrolytes, thyroid function tests, serum B12 vitamin and folic acid levels. Normal sinus rhythm with QTc $318 \mathrm{~ms}$ was seen in an electrocardiogram and no acute intracranial pathology was seen in a cranial CT scan. Young Mania Rating Scale (YMRS) score was 33. She was administered $10 \mathrm{mg} \backslash$ day olanzapine and $2 \mathrm{mg} \backslash$ day clonazepam. At the end of 4 weeks, YMRS score decreased to 14, her manic symptoms improved significantly but she wasn't

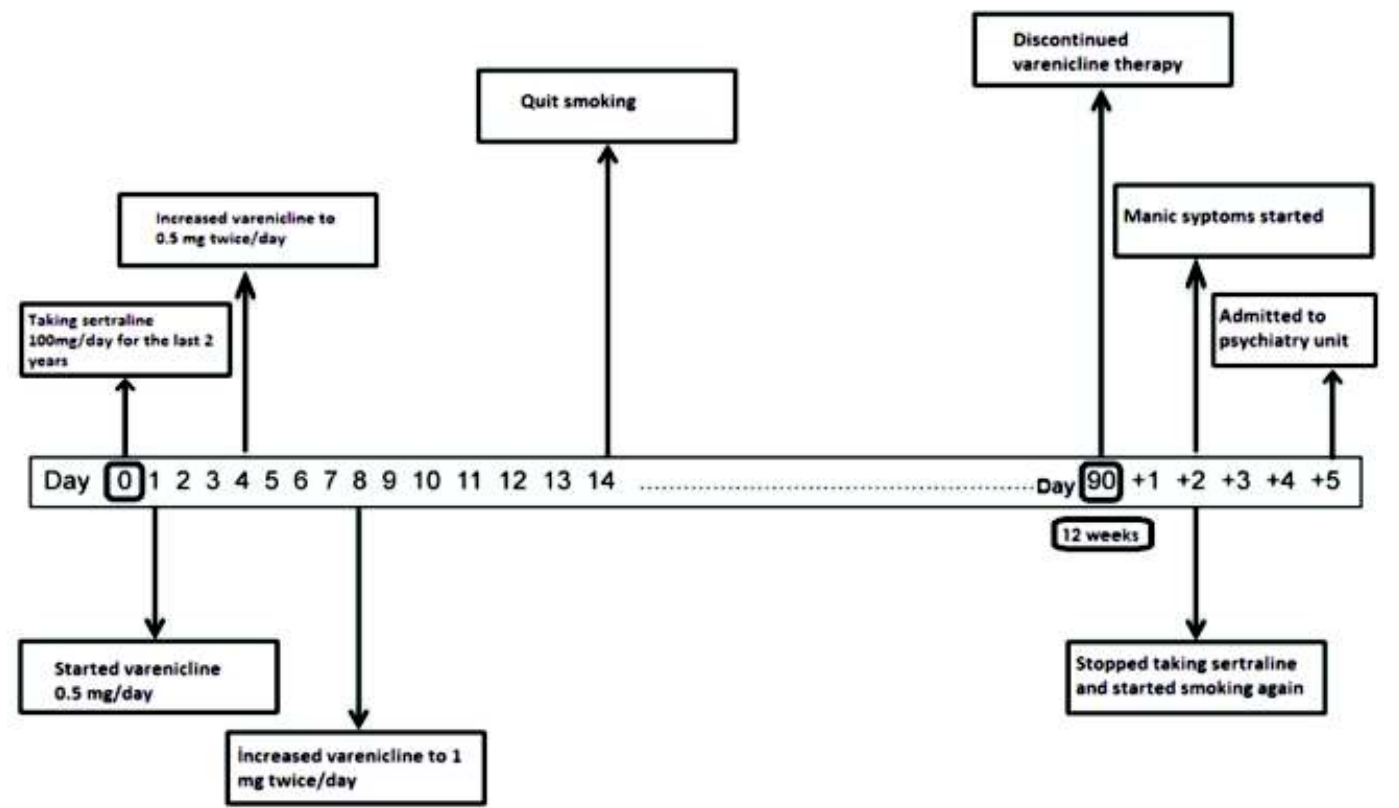

Figure 1: Timeline of the patient's varenicline dosage changes, smoking status and course of manic symptoms 
euthymic yet. On the twenty-eighth day of the hospitalization, the patient was discharged by the request and approval of her family with the treatment of olanzapine $20 \mathrm{mg} / \mathrm{day}$ and clonazepam 0.5 $\mathrm{mg}$ /day. One week after discharge, on her first outpatient clinic examination, she was euthymic with olanzapine $20 \mathrm{mg} / \mathrm{day}$ and her YMRS score was 5 .

Three months post discharge, the patient continued to be free of manic symptoms with compliance with her treatment. However, she showed mild depressive symptoms as partial anhedonia, low mood, fatigue and lack of energy. Her YMRS score was 0 and Montgomery-Åsberg Depression Rating Scale (MADRS) score was 8. In this visit, lamotrigine $25 \mathrm{mg}$ was given to the patient. During followup, lamotrigine was gradually increased to 200 $\mathrm{mg} /$ day and olanzapine was gradually reduced to 5 $\mathrm{mg}$ /day due to sedation side effect. She has remained euthymic with this treatment for the last six years. At the time of writing, the patient was still at follow-up visits and euthymic with the treatment of lamotrigine $200 \mathrm{mg}$ /day and olanzapine 5 $\mathrm{mg}$ /day.

\section{DISCUSSION}

Varenicline behaves like nicotine and provides a continuous medium-dose dopamine release in the mesolimbic system that may change the equation in the cholinergic-adrenergic tone. It is believed to be engaged in the pathophysiology of mania (35). Also, it was hypothesized that the nicotinic acetylcholine receptor may have mood-elevating effects (35). Potent $\mathrm{a} 7$ activation and weak $\mathrm{a} 4 \beta 2$ activation induced by varenicline may cause a central inhibitory dysfunction, which, accordingly, may result in manic symptoms in patients with bipolarity (23). Increasing dopaminergic activity in the central nervous system could also be accounted for the potential for psychotic symptoms $(25,26,27,28)$

There are several case reports of mania induced by initiating varenicline treatment in patients with or without a history of psychiatric illness $(18,19,20)$ $(23,24,25,26,27)(36,37)$ along with reported cases of psychosis about the varenicline withdrawal $(38,39,40)$. In those reports, authors suggested that psychosis may have occurred because of the downregulation of the cholinergic system resulted from an abrupt lack of cholinergic stimulation, which induced an anticholinergic response in individuals with genetic vulnerability $(37,38,39)$. Our case dif- fers from those with the absence of abrupt quit of varenicline during the12-week treatment period. Our patient used varenicline in compliance with her physician's prescription and discontinued following the recommended smoking cessation protocol. She had no mood or behaviour changes during 12 -week treatment period. Given all these things, it does not seem possible that an abrupt lack of cholinergic stimulation-induced mania in our case.

Baker et al. (2016) reported a case of mania with psychotic features subsequent to the exposure to varenicline 3 weeks before self-ceasing the medication (28). The report states that the week following the cessation of varenicline the patient's mental state began to deteriorate and continued to worsen gradually. This case report is claimed to show that it is possible that the withdrawal of varenicline might be associated with mental state disturbances in patients with no pre-existing mental disorder; however, the evidence base is limited.

It is possible that our patient's manic episode was not causally associated with the cessation of varenicline. But it seems likely that indirect dopaminereleasing properties of varenicline may have contributed to the emergence of mania, also antidepressant-like properties may have potentiated the effect of sertraline in a patient with genetic vulnerability and positive family history and a manic shift occurred. The fact that there was no other manic or depressive episode under treatment during the next 6-year follow-up of the patient may also support that a patient in the bipolar spectrum may have developed a mania with psychotic features associated with varenicline.

In conclusion, further research is needed to deepen the data about the safety of varenicline, particularly among smokers with active or previous psychiatric history and with positive family history for psychiatric illness. Meanwhile, physicians should carefully monitor their patients throughout the use of varenicline in concern with mental status in compliance with FDA advice.

*Part of the data was presented at 23 rd European Congress of Psychiatry (EPA 2015), Vienna, Austria, 28-31 March 2015

Correspondence address: M. D. Pınar Kızılay Çankaya, Ankara Training and Research Hospital, Psychiatry Clinic, Ankara, Turkey pkizilay@gmail.com 


\section{REFERENCES}

1. Hays JT, Ebbert JO, Sood A. Efficacy and safety of varenicline for smoking cessation. Am J Med 2008;121: S32-S42.

2. Foulds J. The neurobiological basis for partial agonist treatment of nicotine dependence: varenicline. Int J Clin Pract 2006;60:571-576.

3. FDA Drug Safety Communication: Safety review update of Chantix (varenicline) and risk of neuropsychiatric adverse events [1024-2011]. [Internet]. [cited 24 September 2014]. Available from: http://www.fda.gov/Drugs/DrugSafety/ucm276737.htm.

4. Cahill K, Stead LF, Lancaster T. Nicotine receptor partial agonists for smoking cessation. Cochrane Database Syst Rev 2011;18: CD006103.

5. Cahill K, Stevens S, Perera R, Lancaster T. Pharmacological interventions for smoking cessation: an overview and network meta-analysis. Cochrane Database Syst Rev 2013;31: CD009329.

6. Hartmann-Boyce J, Stead L, Cahill K, Lancaster T. Efficacy of interventions to combat tobacco addiction: Cochrane update of 2013 reviews. Addiction 2014; 109: 1414-1425.

7. Cahill K, Stevens S, Lancaster T. Pharmacological treatments for smoking cessation. JAMA 2014; 311: 193-194.

8. Tonstad S, Davies S, Flammer M, Russ C, Hughes J. Psychiatric adverse events in randomized, double-blind, placebo controlled clinical trials of varenicline: a pooled analysis. Drug Saf 2010; 33: 289301.

9. Thomas KH, Martin RM, Knipe DW, Higgins JPT, Gunnell D. Risk of neuropsychiatric adverse events associated with varenicline: systematic review and meta-analysis. BMJ 2015;350: h1109.

10. Williams KE, Reeves KR, Billing CB, Pennington AM, Gong J. A double-blind study evaluating the long-term safety of varenicline for smoking cessation. Curr Med Res Opin 2007;23: 793-801.

11. Ebbert JO, West RJ, Rennard SI, Russ C, McRae TD, Treadow J, Yu C-R, Dutro MP, Park PW. Effect of varenicline on smoking cessation through smoking reduction: A randomized clinical trial. JAMA 2015; 313: 687-694.

12. Garza D, Murphy M, Tseng LJ, Riordan H, Chatterjee A. A double-blind randomized placebo-controlled pilot study of neuropsychiatric adverse events in abstinent smokers treated with varenicline or placebo. Biol Psychiatry 2011; 69: 1075-82.

13. Weiner E, Buchholz A, Coffay A, Liu F, McMahon RP, Buchanan RW, Kelly DL. Varenicline for smoking cessation in people with schizophrenia: a double blind randomized pilot study. Schizophr Res. 2011;129: 94-95.

14. McClure JB, Swan GE, Jack L, Catz SL, Zbikowski SM, McAfee TA, Deprey M, Richards J, Javitz H. Mood side-effects and smoking outcomes among persons with or without probable lifetime depression taking varenicline. J Gen Intern Med. 2009; 24:563-569.

15. Purvis TL, Mambourg SE, Balvanz TM, Magallon HE, Pham RH. Safety and effectiveness of varenicline in a veteran population with a high prevalence of mental illness. Ann Pharmacother 2009;43: 862867.

16. Stapleton JA, Watson L, Spirling LI, Smith R, Milbrandt A, Ratcliffe M, Sutherland G. Varenicline in the routine treatment of tobacco dependence: a pre-post comparison with nicotine replacement therapy and an evaluation in those with mental illness. Addiction 2008;103: 146-154.

17. Evins AE, Goff DC. Varenicline treatment for smokers with schizophrenia: a case series. J Clin Psychiatry 2008;69: 1016

18. Ahmed AIA, Ali ANA, Kramers C, Härmark LVD, Burger DM, Verhoeven WMA. Neuropsychiatric Adverse Events of Varenicline: A Systematic Review of Published Reports. J Clin Psychopharmacol 2013;33: 55-62.
19. Alhatem F, Black JE. Varenicline-induced mania in a bipolar patient. Clin Neuropharmacol 2009; 32:117-118.

20. Kohen I, Kremen N. Varenicline-induced manic episode in a patient with bipolar disorder. Am J Psychiatry 2007;164:1269-1270.

21. Morstad AE, Kutscher EC, Kennedy WK, Carnahan RM. Hypomania with agitation associated with varenicline use in bipolar II disorder. Ann Pharmacother 2008; 42:288-289.

22. Liu ME, Tsai SJ, Yang ST. Varenicline-induced mixed mood and psychotic episode in a patient with Schizoaffective Disorder. CNS Spectrums 2009; 14:346.

23. Chang PT and Li CT. Mania induced by varenicline. F1000Research 2013; 2: 183.

24. Pumariega AJ, Nelson R and Rotenberg L. Varenicline-induced mixed mood and psychotic episode in a patient with a past history of depression. CNS Spectrum 2008; 13: 511-514.

25. Gecici O, Nebioglu M, Guven M. Varenicline-Induced Manic Episode. Journal of Mood Disorders 2012;2: 74-76.

26. Francois D, Odom A, Kotbi N. A case of late-life onset mania during Varenicline assisted smoking cessation. Int $\mathbf{J}$ Geriatr Psychiatry 2011;26: 658-659.

27. Akpinar A, Özdamar Ünal G, Atay İM, Gündoğar D, Özçankaya R. Late-life Onset Mania After Varenicline Use: A Case Report. Noro Psikiyatr Ars 2013;50: 372-374.

28. Baker R, Gill N, Parker G. First episode mania following cessation of varenicline. Australas Psychiatry 2016;24: 292-294.

29. Peet M, Peters S. Drug-Induced Mania. Drug Safety 1995;12: 14653.

30. Krauthammer C, Klerman GL. Secondary mania: manic syndromes associated with antecedent physical illness or drugs. Arch Gen Psychiatry 1978; 35: 1333-1339.

31. Evans DL, Byerly MJ, Greer RA. Secondary mania: diagnosis and treatment. J Clin Psychiatry 1995; 56 (suppl 3): 1-7.

32.Goldberg JF, Truman CJ. Antidepressant-induced mania: an overview of current controversies. Bipolar Disorders. 2003;5: $407-$ 420.

33. Barbuti M, Pacchiarotti I, Vieta E, Azorin JM, Angst J, Bowden CL, Mosolov S, Young AH, Perugi G. Antidepressant-induced hypomania/mania in patients with major depression: Evidence from the BRIDGE-II-MIX study. Journal of Affective Disorders. 2017;219: 187-192.

34.Terao T, Tanaka T. Antidepressant-induced mania or hypomania in DSM-5. Psychopharmacology 2014;231: 315.

35. Cousins DA, Butts K, Young AH. The role of dopamine in bipolar disorder. Bipolar disorders 2009;11: 787-806.

36.Hussain S, Kayne E, Guwanardane N, Petrides G. Varenicline induced mania in a 51 year old patient without history of bipolar illness. Prog Neuro-Psychopharmacol Biol Psychiatry 2011;35: 1162 1163.

37. Knibbs N, Tsoi DT-y. Varenicline induces manic relapse in bipolar disorder. Gen Hosp Psychiatry 2011;33: 641.e1-e2.

38. Laine P, Marttila J, Lindeman S. Hallucinations in the context of varenicline withdrawal. Am J Psychiatry 2009;166: 619-620

39. López Arteaga MT, Amo C, Sánchez Morla EM, Sánchez Román M. Induced psychosis after withdrawal of varenicline: a case report. Acta Neuropsychiatrica 2011;23: 252-255.

40. May AC, Rose D. Varenicline withdrawal-induced delirium with psychosis. Am J Psychiatry 2010;167: 720-721. 